\title{
The Sociology of Civilisations: Ibn Khaldun and a Multi-Civilisational World Order
}

\author{
Recep Şentürk and Ali M. Nizamuddin \\ Fatih University and University of Illinois Springfield
}

\begin{abstract}
Due to advancements in telecommunications and transportation over the past century, the world is shrinking and physical boundaries are being eroded. The advent of globalization has facilitated the flow of ideas, values, goods, and people from one part of the world to another. This hyperbolic human activity has altered the structure of inter-civilizational relations and has spawned a spirited debate on how to create a multi-civilizational world order. This paper is critical of contemporary approaches on the subject that envisage the primacy of one civilization on the one hand and a clash among civilizations on the other. By examining Ibn Khaldun's theory of 'Umrän and the discipline of Figh, it argues that these concepts remain relevant for our understanding of the human condition today. While the theory of 'Umrän analyzes political and economic relations at the macro-level, Figh tries to arrange societal relations at the microlevel. This paper also studies the Ottoman legacy since the Ottoman state was founded on Fiqh and the Millet system. It proved to be successful in preserving pluralistic communities based on principles of autonomy and mutual coexistence. Even though Ibn Khaldun was one of the pioneers in the field of civilizational studies, his seminal work is largely neglected in scholarly circles today, both Muslim and non-Muslim alike. The present inquiry seeks to address this shortcoming.
\end{abstract}

\section{Keywords}

Ibn Khaldun, 'Umrän, Fiqh, civilization, Muqaddimah, Ottoman, Millet system, religious communities, sociality, levels of analysis, social and political organization

\section{Introduction}

Recently, civilisation has become a popular unit of analysis in the social sciences, including history, sociology, political science, and international relations. Although the variables of religion and culture are examined in academia, these units of analysis have increasingly become subsumed within the study of civilisation. Depending on the discipline and one's worldview, Islam, Christianity and Judaism are simultaneously referred to as religion, culture and civilisation. A cluster of academics from eclectic fields seek to interpret 
and explicate inter-civilisational dynamics in order to predict the future. Though not as pervasive as it is today, inter-civilisational relations have been a special area of interest since the earliest times, including divergent discourses on methodology and interpretation. How are we to analyse civilisations and inter-civilisational relations? Stated differently, which theories and methods ought we to utilise in civilisational research? The present inquiry will seek to resolve the above questions by comparatively examining theories of inter-civilisational relations, from Ibn Khaldun (1332-1406 CE/ AH 732808) (Ibn Khaldun, 1951) to some contemporaneous approaches on the subject in the hope of amending insufficiencies begotten by the lack of Ibn Khaldun reference, despite 'Umrān (examined below) being his greatest overall contribution.

Ottoman thought has appraised Ibn Khaldun chiefly as a theoretician of civilisation, with Ottoman thinkers rallying to implement his pertinent theory unto their times (Fleischer 1983). Consequently the question that comes to mind at this point is the following. Should we implement Ibn Khaldun unto our age? However, such an academic endeavour is currently absent. In fact, even those who claim to be Khaldunian scholars neglect his work on

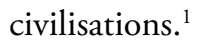

By accentuating the connection between the conception of civilisation nurtured by the discipline of Fiqh, to which Ibn Khaldun belongs, and the discipline of 'Umrān he inaugurated, the paper will offer a contribution to civilisational studies, and will submit two proposals, regarding the disciplines of 'Umrān and Fiqh respectively.

\section{The First Proposal}

Let us consider using Ibn Khaldun's civilisational approach in elucidating empirically the structure of inter-civilisational relations in our age of globalisation. We should also utilise Ibn Khaldun's logic to determine the patterns in the changes civilisations undergo. Ibn Khaldun provides us an alternative to Huntington in explaining inter-civilizational relations. Unlike many who oppose Huntington's ideas, we will not display opposition without proposing

1 This is most palpably exemplified by the special Ibn Khaldun edition of the Journal of Asian and African Studies published, in 1983, commemorating the 650th birthday of Ibn Khaldun, which is notorious for its prevarication of his notion of civilisation. Similarly, despite speaking of Ibn Khaldun's pioneering role in modern sciences, such as anthropology, sociology and pedagogy, the Egyptian sociologist Ali Abdulwahid Wafi, in the preface of the critical edition of Muqaddimah, bypasses Ibn Khaldun's theory of civilisations. 
an alternative. Ibn Khaldun will enable us to construct a new functional paradigm that we can use to explain and interpret civilisations and intercivilisational relations in a globalising world. In responding to such a need, one can not neglect Ibn Khaldun because he is the starting point and the pioneer of rendering civilisation the subject of an independent discipline. He termed this new study 'ilm al'-umrân, science of civilisation.

\section{The Second Proposal}

Let us consider availing ourselves of the normative Figh approach to intercivilisational relations in organising the relations among civilisations in today's world. Presently we are suffering from the torment inflicted by the lack of a global normative order regulating inter-civilisational relations. Throughout the Middle Ages, the Western civilisation failed miserably in instituting a pluralistic normative scheme conducive to the facilitation of distinctive denominations and sects within Christianity, let alone of distinct religions and civilisations. This theological and theoretical shortcoming is also evident in our current secular spheres of law and social sciences, epitomised by the writings of Huntington (1996). From the advent of Islam till the Ottoman demise, the approach of Figh had been utilised by Muslims in governing multi-civilisational societies. As will be examined in greater detail, several of the civilisations analysed by Huntington (1996) had entirely or partially subsisted under Muslim rule bereft of major conflicts.

\section{The Main Debate: Civilisation or Civilisations?}

Before proceeding to our examination of inter-civilisational relations, it is imperative to address one preliminary question; namely, is there a single civilisation, or does humanity possess more than one civilisation? Individual thinkers have exhibited divergent attitudes on the subject and they neglect the contributions of other civilisations on their own. The second vital question is that even though we have hitherto accepted the existence of several civilisations, shall the Western civilisation, henceforth, be considered the sole civilisation of humanity or will other civilisations continue to survive?

In no phase of history has a single civilisation ruled supreme over the entire world; notwithstanding the inveterate efforts of some to do so by eradicating others. Throughout history, humanity has celebrated more than one civilisation. There is no consensus as to the exact number of civilisations; yet, no one doubts the existence of several civilisations. Endorsing this view is Ibn Khaldun who toiled to understand civilisational transformations and conflicts 
during his time. ${ }^{2}$ Also accepting the multiplicity of civilisations is Huntington (1996), attempting in his works to research the changing structure of contemporary inter-civilisational relations.

A multi-civilisational society is only feasible if predicated upon a conception of 'open civilisation'. Insofar as relations with other civilisations are concerned, civilisations may be dually classified as 'open' and 'closed.' Open civilisations acknowledge the right of existence of other civilisations and develop relations embedded in peace. On the other hand, closed civilisations strive for global dominance through the evisceration of other civilisations. Throughout history, no closed civilisation has realised its goal. As unequivocally demonstrated by Andalusian, Mughal and Ottoman experiences, the Islamic civilisation is an 'open civilisation' in that it recognises the right of other civilisations to exist side by side. The West, alternatively, has erected in history a 'closed civilisation' based on Christianity, although today the Western civilisation is advancing a campaign towards becoming an open civilisation by emancipating from being a solely Christian civilisation. However, numerous doubts persist with regard to the future of relations with other civilisations and, in particular, our relations with the Islamic world.

\section{From Hegel to Fukuyama: The Idea of a Single Civilisation}

According to some Western theoreticians - and thinkers who emulate them - there is only one civilisation, toward which numerous nations and cultures, in various stages have provided input; finally reaching its evolutionary zenith with the Western civilisation. The foremost theoretician of this view in our times is Francis Fukuyama (Fukuyama 1992). According to Fukuyama, 'History,' ${ }^{3}$ with capital " $\mathrm{H}$," is a conscious and directional process having completed its evolution with Western liberalism. The 'end of History' thesis is the belief that human society has progressed to the final form of human governance culminating in the triumph of liberal democracy and free markets after the Cold War. Fukuyama points out that liberal democracy, as

\footnotetext{
${ }^{2}$ Ibn Khaldun's work is not reserved strictly to Islamic society and civilisation, in that right at the outset of his book he unequivocally declares his intention of writing a history of the world. For instance Bland appraises Ibn Khaldun's views on the Judaic civilisation (Bland: 1983).

3 Fukuyama makes a distinction between "history" with small case, which is what is commonly understood from the word history, and "History" with capital H. He defines the History with capital H as follows: "History, that is history as understood as a single, coherent, evolutionary process, when taking into account the exprience of all peoples in all times" (Fukuyama 1992: xii). Fukuyama inherits this idea mainly from Hegel and Marx.
} 
we know it today, has emerged in the early part of the 19th century and was one of many alternatives. In essence, the Zeitgeist (spirit of the time) was not democratic. Totalitarianism, fascism, imperial monarchies, and socialism or communism were all considered acceptable forms of organising political and social life. After World War II, all were discredited and human progression during the Cold War led to two competing alternatives of human governance: democracy and free market capitalism on the one hand, and socialism or communism on the other. The collapse of communist political systems, beginning in 1989, discredited the only alternative to democracy and signalled the triumph of the democratic ideal. Communism and the planned method of production were relegated to the ash heap of history, and the Zeitgeist was conducive to the spread of democracy to the rest of the world. Fukuyama asserts:

\begin{abstract}
What is emerging victorious, in other words, is not so much liberal practice, as the liberal idea. That is to say, for a very large part of the world, there is now no ideology with pretensions to universality that is in a position to challenge liberal democracy, and no universal principle of legitimacy other than the sovereignty of the people. Monarchism in its various forms had largely been defeated by the beginning of this century. Fascism and communism, liberal democracy's main competitors up till now, have both discredited themselves. [...] Even non-democrats will have to speak the language of democracy in order to justify their deviation from the single universal standard (Fukuyama 1992: 45).
\end{abstract}

As such, Fukuyama's proclamation of the end of history should not be viewed simplistically as the end of historical phenomena. Instead, his pronouncements should be seen as the end of ideological conflicts since mankind has settled on the democratic prototype. Indeed, the 'spirit of the time' favours democratic tendencies as even non-democratic regimes claim to be democratic. For instance, the Chinese Communist Party has maintained that its expression of Chinese popular will is more democratic then what exists in the United States and Europe. The criticism is that democracy in the West is dominated by special interests of elites who are able to advance their narrow policies and platforms through the various bureaucratic channels. The Chinese government claims to represent the desires of the masses and, as such, is more democratic than Western counterparts. Even brutal totalitarian regimes, like North Korea, espouse the democratic standard in their acronym DPRK (Democratic People's Republic of Korea).

To Fukuyama, the triumph of democratic virtues is undeniable, and this has implications for theory as well as policy. Borrowing from the work of Immanuel Kant and Michael Doyle, Fukuyama argues that the spread of 
democracy not only leads to the end of ideological conflicts but creates a federation of states who do not wage war against one another. According to the democratic peace theory, all democracies have the following in common: freedom from arbitrary authority, political participation, and the protection and promotion of basic freedoms. These commonly shared values among democratic regimes leads to the end of ideological conflicts and the creation of a pacific union of states. Democracies will continue to wage war against non-democracies, but the belief is that they will not wage war against one another.

Evident in such conceptualisations of history is the ideology of Western superiority. Humanity has but one civilisation represented by the West, which societies aspiring to become 'civilised' must wholeheartedly embrace, at the expense of theirs. Like Hegel and Marx, Fukuyama believes that history, since the advent of humanity, is advancing linearly on the path of evolution, albeit the pertinent evolution is not perennial and the path not forever open. Liberal democracy is the final stage of humanity's evolution as propounded by Hegel, while Marx applies this linearity to the culmination of socialism. What this entails for the non-Western societies is the westernisation of their civilisation, as the theory presumes that non-Western civilisations are static and trapped somewhere in a certain phase of evolution. The Western civilisation is impossible to be surpassed. Even its reproduction is inconceivable. This is epitomised in the following quote:

Neither Hegel nor Marx had believed in the unremitting eternal progress of human societies. It was more an acceptance of the seizure of progress once the type of society congruent with the profoundest desires of mankind was attained. Precisely, both thinkers presumed 'the end of history'. For Hegel it was the liberal state, while for Marx, the communist society. Both thinkers held that there would be no further progress in the development of basic principles and institutions as all fundamental quandaries would eventually be solved (Fukuyama 1992:10-11).

Striking is the intense interconnection, in this excerpt, of the notions of 'evolution', 'closed/mortal history' and 'closed civilisation', concepts which in their entirety are evoked to underpin Western-centeredness.

The advocators of a single civilisation and linear history are by no means limited to the examples mentioned above. The tension between the models of 'circular' and 'progressive' history in fact stretches a long way. Judaism and Christianity had bestowed upon social life a novel and unique conception of time which did not exist in antiquity. It could be said that some thinkers from Judaism and Christianity converted the circular notion of history promulgated by Ancient Greeks, typified by Plato and Aristotle, with a progressive 
model, and there is a prevalent affirmation of St. Augustine's (354-430 CE) defining role in the relevant process. Despite the later secularisation of Western thought, this linear and directional conception of time came back to haunt all Western philosophies of history thereafter.

The linear conception of time thus came to replace the circular one, peculiar to natural investigations, in social and historical research. Although the modern theory of history has severed its ties with religion, the progressive perception of time, originating from Judaism and Christianity, persists as a mental formation even today. Without the conceptions of linear time and progressive history, this linear approach to history and the vision of a single civilisation of mankind would have been inconceivable.

\section{From Ibn Khaldun to Huntington: The Idea of Multiple Civilisations}

Contrary to the above approach upholding the notion of a single civilisation, there are also those who argue that there exist multiple civilisations. The paragon example of this view in history is Ibn Khaldun, and among contemporary writers, Samuel Huntington. The fundamental difference between the two thinkers is evinced, however, upon a closer examination of the inescapability of inter-civilisational conflicts and the roots of these conflicts.

The extent of present-day developments in transportation and communication have virtually bludgeoned our understanding of distance and altered the structure of inter-civilisational relations, and a major modification becomes necessary. No civilisation is immune from entering an imperative relationship with others, which unlike previous times, is not just a privilege belonging to geographical neighbours. Therefore, a profound understanding of the contemporary web of inter-civilisational relations is becoming increasingly pivotal. The impact of one civilisation upon another is no longer limited to the frontier as ideas, goods, values, and people cross seamlessly in today's globalised world.

The global developments aforementioned render social research necessary in order that we can examine the penetration of inter-civilisational realities. However, grave differences of opinion exist among social scientists on what constitutes a civilisation and how can inter-civilisational relations be interpreted. This paper will embark upon a comparison of the theory of 'Umrān developed by Ibn Khaldun with other contemporary theories of civilisation. It will be argued that the approach of Ibn Khaldun provides insight to our human condition today.

As a consequence of the developments stated above, 'multi-civilisational' societies have supplanted single civilisational homogenous societies idiosyncratic 
of middle and modern ages. The term 'multi-cultural society' is commonly used by social scientists today. Yet the term 'multi-civilisational society' is new to the pertinent literature. Considering the mutual interplay and coexistence of societies, the term multi-civilisational may be more accurate to describe today's world. Other civilisations are no longer 'out there', but are nearby. The decline of distance and geographical borders has occasioned a macro and micro interweavement of world civilisations.

Insofar as the understanding of a multi-civilisational society and world order is concerned, Ibn Khaldun possesses the greatest explanatory power among current theories of civilisations. For that reason Ibn Khaldun's sociology of civilisations could provide a propitious basis in the search for the establishment of a multi-civilisational world order amid the historical crossroads we are facing. Two interconnected sources underlie Ibn Khaldun's notion of civilisation. The first is the discipline of Figh and the second being 'Umrän. The intellectual foundation of the former was the by-product of his background in the Maliki jurisprudential school in which he served as a jurist, and a high judge (qadil-qudat).

A paradigmatic case of a multi-civilisational society has been the Ottoman State. Here, societies affiliated with a plethora of civilisations lived mutually under the shelter of a single political unit. After the city's conquest, Mehmed the Conqueror desired for Istanbul to continue serving as a centre for Orthodox Christians, which prompted him to continue to sanction Patriarchate activity in the city. Unsatisfied, the Ottomans even went to the extent of establishing the Armenian Patriarchate and the Jewish Rabbinate, upholding the policy of turning Istanbul into a centre for different religions and civilisations. Istanbul, thus, effectively became the single most important global centre for Islamic, Christian and Judaic civilisations, a structure whose remnants are extant even today.

The Ottoman Millah system, founded on Figh, proved to be successful over the centuries in preserving pluralistic communities. Each religious community was jurisprudentially incorporated within the Millah system and was classified as an independent socio-cultural unit. In accordance with Fiqh, the only prerequisite of being inducted as a member of the society of civilisations, as stipulated by Islam, was the acceptance of Darüriyyant (axiomatic principles and rights) which was also called Kulliyyāt (universal principles). ${ }^{4}$ Darüriyyät was comprised of self-evident axiomatic principles governing human relations accepted unconditionally by everyone from different civilisations.

4 The relevant universal and axiomatic principles are based upon the six inviolable rights, namely those of life, property, religion, mind, dignity and family-progeny. 
What was, thus, expected from a prospective civilisation aspiring to join the society of civilisations was merely a pledge of abidance by the principles already accepted beforehand, and there existed no such demand to embrace any forms of novel values. Keeping with Fiqh, the pertinent axiomatic principles and universal principles consisted of basic human rights that guaranteed the inviolability of a person's life, property, religion, intellect, family and dignity. By all means, various civilisations were permitted to establish distinct values apart from the sphere of Darüriyyat. Fiqh was triumphant in mediating between universalism and parochialism, preserving cultural identities on the one hand, and constructing an inclusive platform of coexistence on the other.

Here, the inspiration behind Ibn Khaldun's thought and Figh needs reiteration. Being a jurist of the Maliki School, Ibn Khaldun's cogitations of history and civilisation are the by-product of his legal knowledge. ${ }^{5}$ The essential source of his revenue throughout the greater bulk of his life came from lecturing on Figh at Al-Azhar University in medieval Cairo, which was one of the leading centres of scholarship at the time. He often served as a high judge in the multi-civilisational societies that extended from Andalusia and Morocco to Egypt and Syria. For this reason, a multi-civilisational social order is accepted in his Muqaddimah as an incontrovertible reality, and there is no mention of encouraging Islam's obliteration of other civilisations in order to exercise hegemony over them.

It remains quite plausible even today to draw from this theoretical approach in comprehending and organising inter-civilisational relations. Phrased plainly, will the Western civilisation at the apex of current global power emulate the Islamic model of the Middle Ages and allow for the survival of other civilisations? Or, will it seek global dominance and homogeneity? At this important juncture, the vitality and potential contribution of Ibn Khaldun becomes manifest, especially when juxtaposed to Western notions of global pre-eminence.

An Ibn Khaldunian approach based on civilisational pluralism will prove invaluable for the Western civilisation. This is because Western civilisation has yet to develop the conceptual and institutional paraphernalia to provide a

\footnotetext{
5 In his article on Ibn Khaldun, published for the first time in 1933, Gibb attempts to demonstrate the importance of the influence of being a Maliki jurist has had on the thought of Ibn Khaldun. The same emphasis is made also by Franz Rosenthal, an translator of Muqaddimah to English, and Bruce Lawrence. For Gibb's ideas underlining the necessity of appraising Ibn Khaldun as a Maliki jurist, see (Gibb, 1962: 166-175). For Franz Rosenthal's call to understand Ibn Khaldun in the context of his era wherein religion and science has not yet separated, see (Rosenthal, 1983: 166-178). For Bruce Lawrence's writings accentuating the importance of Ibn Khaldun's allegiance to Islam, see: (Lawrence, 1983: 154-165, 221-240).
} 
bulwark against inter-civilisational clashes. Ibn Khaldun thus confers an opportunity inasmuch as his civilisational approach markedly differs from Western theoreticians like Toynbee, Huntington and Fukuyama.

\section{Ibn Khaldun's Sociology of Civilisations and Macro-Fiqh}

For humans who inhabit a multi-civilisational world, it is an insurmountable need to understand civilisations and how to organise relations among them. This effort will imperatively entail a macro sociological analysis. ${ }^{6}$ Throughout Islamic history, this problem has occupied the agendas of historians and jurists alike, which has contributed to the advent of pluralistic societies. Simultaneously in the West, however, these precise issues of multi-culturalism and multi-civilisationalism were disowned, and even feared. Ibn Khaldun's framework is an analysis at the macro level and this realisation necessitates the prior construction of units of analysis.

In accordance with this objective, Ibn Khaldun generally makes use of three terms: Madaniyyah, 'Umrān and Ijtimä. He contends that all three are synonyms inherently expressing the same concept: civilisation. To these three terms, Ibn Khaldun also adds Millah. Noteworthy is the fact that his overriding preference lays with the terms 'Umrān and Ijtima', and he recoils from the excessive use of Madaniyyah which he divulges is a term peculiar to philosophers. He uses 'Umrān and Ijtima to explain the social structure of a civilisation, and in contrast, he uses Millah to highlight the cultural and religious configuration of it.

It is erroneous therefore to assume - contrary to ungrounded conventional contentions - the word Madaniyyah to be a 19th century translation of the Western term "civilisation" and, similarly, Ijtimä to be a modern translation of sociology. Both Madaniyyah and Ijtima $\vec{a}$ were already profoundly anchored concepts of Islamic and Turkish thought, an argument we can vindicate by referring to Ibn Khaldun's work and translation by Sheikh'ul-Islām Pîrizāde Mehmed Efendi (1674-1748 CE).

Ibn Khaldun begins the prologue of the opening chapter of the first book of Muqaddimah as follows;

${ }^{6}$ Preponderantly, two types of analysis are undertaken in sociology: micro (on an individual scale) and macro (on a group scale). A micro analysis concentrates on individuals' social relations, behaviour or actions. A macro analysis, on the other hand, investigates the behaviour and relations of groups or corporations. The unit of micro analysis is the individual, while of macro analysis is the corporate social actor such as family, state and civilisation. 


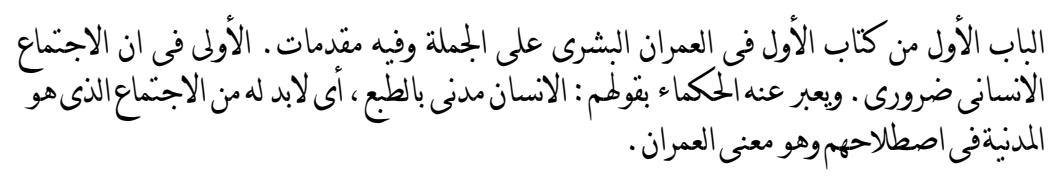

The opening chapter of the first book pertains to anthropic 'Umrän in general. Here prevail some premises (muqaddemät), first of which is: It is of necessity for humans to live communally. Hukema (philosophers) articulate this as such: Humans are naturally predisposed to sociality. That is, humans cherish an absolute need to society ('Ijtimä), which in their terminology corresponds to Madaniyyah, which in turn denotes 'Umrän (Ibn Khaldun 1981: I, 337).

The excerpt illustrates Ibn Khaldun's emphasis towards construing 'Umrān, Madaniyyah and 'Ijtimä' as cognates. Let us now inspect Pîrîzāde's translation of the relevant section:

Section One: (It) is in elucidation of the sociality, across countries and regions, of the sons of Adam residing in the prosperous world. A few prologues are comprised in this section, first of which clarifies the imperativeness of human beings to reside and dwell communally in districts. Precisely, it is unfeasible for human beings to dwell like animals in solitude and it is a corollary of their nature to at all times seek collectivity in dwelling and abode. Philosophers, enthused by this sociality, have defined this circumstance by asserting 'humans are naturally predisposed to sociality', and in their terminology, civilisation (Madaniyyah) consists in the sociality of mankind on the realm of earth. In fact, as the word medina (city), in the Arabic language, is affixed to cities wherein humans are socially gathered individually and in numbers, such is the explanation... (Ibn Khaldun 1275: 48-49).

The death of Sheikh'ul-Islām Pîrîzāde Mehmed Efendi, the first person to translate Muqaddimah from Arabic to Turkish, was in the first half of the 18th century. This establishes the fact that the term Madaniyyah, meaning civilisation, was not a novel concept bequeathed onto Turkish thought from the West during the Tanzimat period (late Ottoman reforms). As we noted earlier, however, classical Islamic thinkers favoured other synonymous concepts in place of Madaniyyah, which became fashionable only in the concluding phase of the Ottomans. In passing, as will be elaborated shortly, one must remind the reader of the misuse of Madaniyyah by some Western writers, which is also true for Millah. ${ }^{7}$

7 The existence of concepts whose corresponding social actualities have ceased to exist may only subsist on the abstract mental level, which may not be always possible. Or these concepts may undergo a shift in meaning, becoming utilised to designate other phenomenon. Concepts like Millah and Madaniyyah (nation and civilisation) pose as astonishing instances to this 
Judging from the above excerpt, the history of the concept of civilisation as a unit of analysis employed in sociological investigations can be traced back, at least, to Ibn Khaldun and even to earlier philosophers, such as Farabi, Ibn Sina and Ibn Rushd. Examining their approach to civilisation can prove to be very beneficial, but that beckons for a separate research.

There are three fundamental reasons, Ibn Khaldun argues, for humans to lead a social life: need for nourishment, security and companionship. These needs can only be met by living in sociality. Civilisation is thus imperative insofar as it accommodates for these three essentials. Humans detached from leading a social life cannot satiate these needs through any other means, hence the actual impossibility of Ibn Tufayl's fantasy Hayy ibn Yakzän or Robinson Crusoe. A mighty ruler or state who establishes the rule of law to obviate social conflict is incumbent upon human beings to maintain social order. Otherwise people would annihilate one another through force. However, argues Ibn Khaldun, the past demonstrates that it is not of historical necessity that this ruler be a prophet, or the administration be based on divine revelation because societies without a prophet or divine law have existed in bygone periods.

Furthermore, it is not obligatory that all humans establish similar social orders. On the contrary, the process of social or civilisational formation is voluntary $(i r \bar{a} d \bar{\imath})$, whereas animal communality is instinctual $(i / h \bar{a} m \bar{\imath}) .{ }^{8}$ Humans are bound to establish distinct social orders. Thus, the social organisation of animals is monotonous, whereas human societies and civilisations display variances. As has been argued by Islamic scholars, since God has withheld reason from animals, He has recompensed that through instinctual guidance which inspires animals to set up similar communities irrespective of where they inhabit in the world. What seems to elicit Ibn Khaldun's astonishment

circumstance. Although in classical Islamic thought, the term Millah had been used to denote a religious community, as a result of a shift in meaning, it has been impregnated, nowadays, with racial connotations. The greatest cause of this meaning shift has been the obliteration of the actuality to which the concept Millah corresponded, following the destruction of the Ottoman Millah system. Again, current implications of the widespread term Madaniyyah, is a certain level of development, unlike Ibn Khaldun or Pîrîzāde, who had construed it as 'Ijtimä or 'Umrān. Consequent upon a projection of the current meanings of such terms in readings of classical texts or vice versa will doubtless be anachronism. No such consensus exists even today with regard to the definition of civilisation, thus professing whichever thinker's conception of civilisation we are using may hinder possible conflicts.

8 The concept $i l h \bar{a} m \bar{\imath}$ here is used as an antonym of $i r \bar{a} d \bar{\imath}$ and designates the behaviour of animals as inspired by God. Today the same occurrence is labelled as instinctual, according to which actions of animals are characterised. 
however are human societies, exhibiting differences, and formed amid a voluntary process of the human will.

From this it must not be construed that Ibn Khaldun envisages human will as the sole founding element able to accomplish everything within its desire. Humans are the by-product of their socialisation as their economic structures, political institutions, and cultural orientations place limitations on their behaviour. The structure-agency ${ }^{9}$ tension (Sewell, 1992: 1-29) is perceivably reflected in Ibn Khaldun's work, without sacrificing one for the other to the point of becoming ensnared by a deterministic attitude. A deterministic attitude exclusive of agency can be applied to animal packs, the upshot of the intuitive process that displays uniformity throughout the world. However, a reciprocal impact holds sway in human societies between structure and agency. Within the perplexing process of history and society, the human will plays a role, albeit to a limited extent.

The attempt to render civilisation, as a product of human will operating within the constraints of social and historical laws, into the subject of an independent discipline belongs to Ibn Khaldun. He personally recounts with satisfaction that he turned it into an autonomous inquiry what had been previously examined as a secondary approach by other disciplines. Ibn Khaldun mentions that theologians and jurists from previous generations had appraised the matter of civilisation simply as a topic in their own scholarly discussions. According to Ibn Khaldun, Muslim theologians adduced the founding of society as a proof necessitating prophethood, ${ }^{10}$ and jurists regarded the protection of civilisation among the objectives of Fiqh. Ibn Khaldun additionally accentuates the jurists' emphasis on the role of language in social communication as an imperative of catering to social needs. To cite an example, the Risālah of Shafii, Mustasfā of Ghazzāli and Mahsūl of Rāzī predominantly engage in linguistic and hermeneutic debates, disclosing explanations relating to the interpretation of both holy texts and human discourse.

Another area of confluence between Ibn Khaldun's 'Umrān theory and jurisprudential (Fiqh) thought is to be found at the level of analysis. On the whole, Ibn Khaldun undertakes a macro level analysis in Muqaddimah. Fuqahā thinking alternately examines human action simultaneously at the macro and micro levels. The construction of the units of analysis on the

9 The subject dealt with in contemporary sociology as the relationship between structure and agency, remains a pivotal area of debate, detaining the attention of many sociologists.

10 Mutakallimün or the Muslim theologians hold that an ideal society may only be founded by a prophet receptive of divine revelation. Concomitantly, an ideal society is governed by norms based on revelation; hence the unassailable need, as per mutakallimün, for prophets in mankind's process of instituting society. 
macro level may bear similarities as well as differences. In Figh, the concept Millah is used to denote civilisations and societies with distinct cultures. ${ }^{11}$ Ibn Khaldun is no stranger to the concept of Millah, although he develops a classification that incorporates economic and political structures and their phases of historical change. Therefore, the terms 'Ijtim $\vec{a}$ ' and 'Umrän are more congruent with this overall purpose.

As such, two classifications, accentuating different aspects of civilisation, emerge in the Islamic tradition; namely, the cultural approach of the jurists, and the economic and political approach of Ibn Khaldun's 'Umrān discipline. Ibn Khaldun, a Maliki jurist and historian, has effectively made use of both.

Quite discernible is the jurisprudential impact upon Ibn Khaldun, particularly, staying loyal to our subject, the subsequent factors:

(1) The outward-inward differentiation: Figh deals with human behaviour, demarcating the outward (observable) and inward (unobservable) aspects of actions and social phenomena, an ontological, epistemological and methodological separation. Fiqh accepts that each deed is at once inward and outward; by inward is meant the undetectable aspect of human behaviour, not the mysterious or esoteric immune to comprehension. ${ }^{12}$ Likewise, Ibn Khaldun's accent on bätin (i.e., esoteric) has nothing to do with the Bātiniyye movement. ${ }^{13}$ Intentions, for instance, as conceded by jurists in their entirety, belongs to the inner part of the deed. Inward and outward are even considered as the two sub-branches of Fiqh. In tandem, as history has inward and outward aspects, Ibn Khaldun affirms, historiography takes to task the outward of history, while 'Umrān delves in to its innermost. Becoming transparent here is the espousal of a multi-layered conception of being, in that 'outwardly', history is but conveying data pertaining to prior eras, states and previous generations of foregone ages, whereas 'inwardly', history is cogitation (nazar), investigation (tahqiq) and the explication of facts within the chain of cause-effect, and its principles are meticulously refined (Ibn Khaldun, 1981: I, 282).

(2) Levels of analysis: A macro level social analysis is undertaken with and as a complimentary of that of a micro level. Reminiscent of the emphasis of Figh on the actions and relations of humans individually

11 Through the Millah (in Turkish millet) system, the fuqaha were able to obviate conflict among civilisations they classified according to difference in culture, or more precisely religion.

12 For Ibn Khaldun's effort of delving into the esoteric dimension of history, see (Lacoste, 1984: 149-150).

${ }^{13}$ For Ibn Khaldun's conception of science, refer to (Ahmad, 2003). 
and communities collectively, Ibn Khaldun lays the accent on 'Umrän and sociality, examining various phases of 'Umrän and their relations with each other.

(3) Method: Ibn Khaldun has applied many methods current in the methodology of Figh to the discipline of 'Umrän, the most important of which is analogy (qiyass), where Ibn Khaldun argues for the need to compare unobservable phenomena with the observable. ${ }^{14}$

The inference from what has been articulated thus far is that Muslim philosophers, jurists and theologians had indeed conducted macro level analyses on civilisation and society, without, however, envisioning it as a subject-matter of an independent discipline. Ibn Khaldun's contribution precisely lies in his ascertainment of the vitality of society and civilisation, hitherto studied as a bare subject, and its transformation into the subject of a new discipline.

One feature, however, needs an emphatic reiteration. Ibn Khaldun's conception of civilisation differs from previous and contemporaneous thinkers. Dovetailing his idea of civilisation with the contemporary approach would lead us to make grave mistakes of scholarship and judgment of civilisations. Such a mistake would be a manifest case of anachronism, which is the root cause of the misunderstandings of contemporary interpreters of Ibn Khaldun, Muslims and Westerners alike. Perhaps the best illustration of this anachronism is epitomised by the opinion of many commentators that envisage Ibn Khaldun as the pioneer of positivist social science. Regardless of Ibn Khaldun's lead in those fields, depicting him as inclining toward a positivistic attitude would at best be preposterous, as mentioned above. He transcends positivism by virtue of acknowledging the inherently inward and outward scopes of history.

As mentioned above, the difference between Ibn Khaldun's concept of civilisation and the modern understanding of it is not literal. But there are differences of essence, and these differences need to be exposed. Not only are there differences between Ibn Khaldun and Western thinkers, but there are doubtless disparities between Ibn Khaldun's concept of civilisation and that of other Muslim intellectuals. Again, this notion of anachronism constitutes the fundamental reason as to why Ibn Khaldun is misunderstood by both some Western and Muslim interpreters.

Another facet that demands attention is the branding of Millahs (religious communities) as civilisations. In classical Islamic thought, religious communities

\footnotetext{
${ }^{14}$ Ibn Khaldun argues through analogy (qiyās) of the past with the present and of the unobservable with the observable for the possibility of refraining from some superstitious construal of historical events.
} 
are referred to as Millah which literally means nation. Presently, this term is replaced with the term civilisation. Instead of the term 'Islamic nation', for instance, the term 'Islamic civilisation' is commonly adopted. Similarly, the usage of the appellation 'Judeo-Christian civilisation' is widespread to designate the Western civilisation. Noam Pianko has commented that Mordecai Kaplan's groundbreaking definition of Judaism with the term civilisation is a significant contribution to modern Jewish thought (Pianko, 2006: 39-55). The same applies also to Islam, Christianity and Buddhism, religions all redefined as civilisations. This has been exemplified by Huntington's classification of the world into civilisations based on differences of religion. The units Huntington refers to as civilisation were termed Millah by Fuqahā.

The shared quality of the approaches of the Fuqaha and Huntington is their cultural and religious undertones. Yet Ibn Khaldun pins the concept of 'Umrān onto a more political and economic basis. The nomadic and sedentary 'Umrāns may have currency in all cultures and religious societies. Hence, Ibn Khaldun's emphasis, unlike Huntington, is on the type of social, political and economic organisation instead of religion.

Despite these major differences, the approaches endorsed by Ibn Khaldun, the Fuqaha and Huntington share a common denominator. All argue that no society is external to civilisation. The jurists believe that each society is ineluctably a part of Millah, and Ibn Khaldun asserts that each society possesses an 'Umrān, whether nomadic or settled. ${ }^{15}$ Similarly, according to Huntington, each society is a member of a civilisation. As such, the concept of 'Umrān, upon which is incumbent the responsibility of analysing on a macro level and arranging all social relations, is only possible with the concepts of civilisation or Millah.

However, while classical Islamic thought endows social and legal equivalence to Millahs and 'Umräns, Huntington advocates the superiority of the Western civilisation which is predicated upon universal human rights and individual freedoms. He contends that other civilisations either completely lack these ideals or developmentally lag behind the Western prototype. Even though Huntington may accept that all mankind is affiliated with a civilisation, he does not consider all of them on an equal par with the Western civilisation, and this accentuates notions of Western superiority.

15 Badāwah and hadārah (nomadicness and settlement) are two characteristics affixed to 'Umrān, with which we will deal in greater detail in our evaluation of the accidents of civilisation below (Ibn Khaldun, 1981: I, 287). Ibn Khaldun thus holds that nomads also possess an idiosyncratic civilisation. This approach is patently the opposite of that which uses civilisation to define societies evincing a certain level of 'development'. 


\section{The Discipline of 'Umrān and Its Essential Accidents}

History, as indicated above, has two strata: inward and outward. On the outward surface, the discipline of history communicates past events, civilisations and states, by the narrative method, while inwardly, it undertakes an interpretation by means of cogitation, investigation and inference (Ibn Khaldun, 1981: I, 276). Insofar as their subject-matters are concerned, Ibn Khaldun notes a resemblance between political science and rhetoric, albeit underlining significant divergences between the two.

Methodologically, disciplines during the time of Ibn Khaldun were categorised into two, namely khatäbi (rhetorical) and burhāni (rational). Historical sciences were predominantly regarded under khatäbi disciplines, and the burhäni section boasted branches such as philosophy, methodology of Fiqh and Kaläm. Ibn Khaldun held that although 'Umrän externally uses narration, a method characteristic of the khatābi method, it ultimately is a discipline that internally employs a rational method, a trademark of the latter.

Ibn Khaldun embraces traditional metaphysics predicated upon a separation of essence (jawhar) and accident ('arad). In terms of basic attributes, Ibn Khaldun believes all civilisations carry similar structural qualities, which he labels al-avärid al-dhätiyye, essential accidents. The following citation sheds light on his objective in Muqaddimah:

In it (Muqaddimah) I have expounded, in a manner beneficial to you, the states of 'Umrän and of establishing civilisations, the essential accidents emerging in human society, including their causes and effects (Ibn Khaldun, 1981: I, 286).

In the excerpt below, Ibn Khaldun uses rational proofs to elucidate the causes and effects of the essential attributes of civilisation. His classifications of the essential attributes of civilization are based on dichotomies such as state-nation, town-village, dignity-abasement, prosperity-scarcity, science-art, increase-diminution, nomadic-settled, and present-future:

Let it be manifest that the reality of the discipline of history is to impart knowledge of human society, the 'Umrän of the universe, and conditions affixed to its nature, like solitude, harmony, tribalism, human hegemony over one another and the entailed kingship, states and their levels, human acquirement incurred by their works such as gain, imbursement, sciences and crafts, and of the conditions that emerge naturally in the pertinent 'Umrān (Ibn Khaldun, 1981: I, 287).

A rough enumeration of the 'accidental qualities' (i.e., non-essential and changeable qualities) of a civilisation as adumbrated above would include the 
following: state, nation, religion, town or village, progressiveness or backwardness, over-population or under-population, nomadic or settled, present or impending, solitude, harmony, group-feeling, triumph, hegemony, kingship, authority, profit or loss, subsistence, sciences and the arts. Each discipline in Ibn Khaldun's era studied the essential-accidents of its subject-matter. The chapters of Muqaddimah have been organised according to the essentialaccidents of civilisation. This way the book provides analysis of each essentialaccident of civilisation.

Essences characteristically are impervious to change, while accidents are predisposed to it, which bestows 'Umrān a dynamic character, to the extent that its accidents are in a process of continual alteration. The subject-matter of 'Umrān, far from being static, is constantly changing. This fact is emphasised by Ibn Khaldun lamenting one implicit mistake of historiography as the failure to acknowledge the social transformation incumbent upon future generations imperatively incurred by fleeting times and centuries, which he classifies as a covert and menacing illness (Ibn Khaldun, 1981: I, 320).

Human civilisation or society, Ibn Khaldun contends, ought to be the subject of an independent discipline. The subject of this discipline should be conditions and accidents attached to civilisation and society. In other words, it should exclusively undertake the investigation of the essential-accidents of civilisation.

We have already mentioned Ibn Khaldun's sensitivity in stressing the need to discern between 'Umrān and political science, especially in terms of their similar subject-matter (Ibn Khaldun, 1981: I, 332). The distinction between the two should be readily apparent, in that while the discipline of 'Umrān inherently carries all the accidents of civilisation, political science exclusively examines politics. The difference between rhetoric and 'Umrān, on the other hand, as already indicated, pertains not as much to their subject-matters, but rather to their methods. Rhetoric is almost entirely devoid of a specific subject. The dividing line between rhetoric and other disciplines is in the use of evidential method.

Issues within the parameters of 'Umrān, Ibn Khaldun states, are equally current in the burhānì disciplines of philosophy, Kalàm, and methodology of Fiqh. In substantiating the need for prophethood, philosophers and scholars alike, contend that the innate need of humans for collaboration to provide continual subsistence entails the need for a ruler. Correspondingly, in explicating the existence of various languages, the methodology of Fiqh deduces that humans, as a corollary of the nature of social life and solidarity, evince the need of articulating their thoughts, from which stems variations of expression. Similarly, jurists deduce legal (shar $\hat{\imath} \hat{)}$ ) principles with their intent (maqāsid), 
constructing a judgment on the cause ('illah) of relevant intent. Thus, the prohibition of adultery is to protect progeny, and the injunction forbidding murder is to guard the human race. The existence of oppression leads to the demise of civilisation. The entirety of this intent, Ibn Khaldun asserts, is based upon the foundation of protecting civilisation, rendering incontrovertible the need incumbent upon jurists to undertake theoretical cogitations and propound theories regarding the attributes of civilisation (Ibn Khaldun, 1981: I, 332-333).

Civilisations rise and fall with their accidents, whose existence, in turn depends on the existence of the civilisation, and vice versa. The collapse of a civilisation tears down its sciences and arts. This reality can best be understood by an examination of the contemporary Islamic civilisation.

\section{Civilisation, the Nature of Power, and Conflict}

Political authority occupies a pivotal place among a civilisation's essential accidents. Ibn Khaldun contends that the nature of power requires monopoly (i.e., possession of power under a single authority), or in the academic lexicon, hegemony (Ibn Khaldun, 1981: II, 539). This unavoidable struggle for power leads to conflict between powers claiming ownership of authority.

Ibn Khaldun has constructed his theory of 'Umrän on a double-layered dialectic: internal conflicts and external conflicts.

(1) Internal conflicts and the continuous cycle of ruling elites: Ibn Khaldun places great relevance on the dynamics of internal civilisational conflicts. In each society, the status of the administrative class is a cause of unremitting conflict in which tribalism is paramount. The impossibility of the perennial protection of the status of a given administrative class leads to the susceptibility of a continuous cycle of change.

(2) External conflicts and the continuous cycle of civilisations: In examining the venture of civilisations, Ibn Khaldun was not merely content with investigating their inner dynamics. He also analysed the variable of the relations of a given civilisation with others. Insofar as civilisations cannot subsist in solitude, they are accordingly interlocked in relationships with other civilisations. This, time and again, has led to conflict, not from differences of values, but from the desire to establish hegemony over other civilisations.

A strong civilisation has the disposition for augmenting its power and gradually acquiring global supremacy. Weak civilisations, Ibn Khaldun believes, 
irrevocably imitate the strong, foremost in ideology, fashion and custom (Ibn Khaldun, 1981: II, 510). A mode of relationships, however, is not eternal, and positions in time are liable to alteration. The strong becomes the weak, and vice versa, through which world civilisations undergo a continuous cycle.

From the vantage point of historical and social principles, Ibn Khaldun perceives no difference between the Islamic civilisation and others. All civilisations operate in accordance with the same laws, and religious differences do not ipso facto develop into inter civilisational political and economic clashes. The Islamic civilisation, however, differs from other civilisations primarily by the fact that the pertinent civilisation is predicated upon the naqli (revelational, traditional) sciences. Accentuating the mutuality of rational sciences in all civilisations, Ibn Khaldun is quick to underline that naqli or traditional disciplines initially derived from divine revelation to Prophet Muhammad (Tafsìr, Hadìth, Fiqh, and Kalām), are exclusively peculiar to Islam. ${ }^{16}$ Following an outline of traditional sciences and their connections to one another, Ibn Khaldun notes the following observation. He states, "The entirety of these naqli sciences is idiosyncratic of the civilisation of Islam and its folk" (Ibn Khaldun, 1981: III, 1027). The decline of 'Umrān in the Maghreb (North Africa), Ibn Khaldun detects, and the rupture of the chain of hadith transmission, were the root causes in the downfall of scholarship.

\section{The Past and Future of the Problem of Multiplicity of Civilisations}

The agenda of creating a world order which is characterized by the multiplicity or plurality of civilisations occupies the attention of the world today. Recently, two distinct attitudes are observable. The first involves lending support to Western domination, while the second advocates the cause of forming a new world order wherein all civilisations partake in equal relations. The Western experience of civilisational relations pre-eminently condones the first option, whereas the Islamic experience paves the way for the latter. Historically, this phenomenon had been triumphant as Islam incorporated other civilisations. Islamic civilisation presided over other civilisations by developing a political edifice which provided them freedom of existence, and was analogous to a federation of civilisations. So where exactly, in this context, does Ibn Khaldun stand?

\footnotetext{
${ }^{16}$ Ibn Khaldun writes in the Muqaddimah that "Wa hädhihi'l-ulüm al-naqliyye kulluha mukhtassah bil-milletil-Islämiyye ve ehlihä" meaning that "these revelational-traditional disciplines exclusively belong to Islamic civilisation and its people” (1981, III, 1026-1027).
} 
As substantiated above, Ibn Khaldun is the founder of an independent discipline perusing civilisations. It is reprehensible that the Ibn Khaldunian approach defiantly receives but scanty attention in contemporary debates of inter-civilisational relations. Despite exalting Ibn Khaldun for his cutting edge studies in politics, economics, sociology, history, and so forth - to the point of even declaring him as the father of the pertinent disciplines - one cannot help but be astounded as to the lack of attention he elicits in the debate surrounding civilisations presently (Al-Azmeh, 1982).

In our contemporary world of globalisation, does Ibn Khaldun have nothing to offer to the current discussions of civilisations and inter-civilisational relations? Or, is the approach of Ibn Khaldun consigned to disrepute simply for running counter to the dominant paradigms? Does the discipline of 'Umrän have anything to offer to the current colloquium? Or, should it be retired to its resting place in the history of thought? The rest of the paper will try to tackle these inquiries.

An adequate understanding of the potential functionality of the discipline inaugurated by Ibn Khaldun imperatively requires an inspection of the nature of the milieu from which it blossomed, and its similarities with the milieu we inhabit today. After examining his study, it is evident that Ibn Khaldun's inquiry was the by-product of the changes and conflicts of the multi-civilisational societies during his time that extended from Maghreb to Mashreq, or from West to East (in today's terms, from Spain-North Africa to the Middle East). Ibn Khaldun, like every social scientist, attempted to pierce into the phenomena occurring in his society, and in hindsight, his thought had reflected a pluralistic social experience.

As such, are we today in an inescapable position of comprehending and predicting the future of the society wherein we reside? Today's world is increasingly assuming a pluralistic disposition, a feature which indeed strikes a chord with the world Ibn Khaldun had witnessed and appraised in his work. Due to these similarities, Ibn Khaldun's discipline of 'Umrān has the potential of being pertinent to the study of the contemporary multi-civilisational experience. We can apply Ibn Khaldun's theory of civilisation and the relations among civilisations to explain contemporary civilisations and their relations with each other.

Ibn Khaldun's approach regarding civilisations is a product of a multi-valued logic. While inter-civilisational relations throughout the Middle-Ages were handled with a dual logic, it was the multi-valued logic which attracted the preference of the Islamic world. Precisely expressed, while the domineering entities of the West during the Middle Ages divided the world into 'us' and 'others', Muslims established multi-civilisational or multi-cultural societies. Today, it is of necessity to comprehend inter-civilisational relations through a 
sociological approach based on a multi-valued system of thought. In contrast, attempting to interpret the world by slicing it into the Western and the NonWestern halves would lead to serious quandaries. The dualistic logic is reductive; it attempts to homogenise, simultaneously, 'us' and the 'other', although neither 'us' nor the 'other' is homogenous.

A multi-valued logic alternately allows 'us' to deal with the domain of the 'other', but not a single 'other,' through the recognition of the equality of all civilisations at the social level. The implementation of the pertinent equality pertains to social relations and not on the sphere of theological beliefs. Civilisations that differ theologically are bound to foster truth claims that are not ecumenical. Besides, such an attempt of reconciliation would contradict the ideal of pluralism, inasmuch as it would be tantamount to formulating a single theology to preside dominantly over the entire world. Instead, setting aside religious and theological differences would doubtless be of greater benefit.

Pluralism accordingly conceived is manifest in Ibn Khaldun's approach to civilisations. Emphasising that constructing a civilisation is a process of will, Ibn Khaldun simultaneously points out the propensity of human will and reason toward reaching varying conclusions. Ibn Khaldun argues for the possibility of the existence of secular civilisations. This is in sharp contrast, as aforementioned, to Muslim thinkers of that period who regarded the impossibility of the construction of a civilisation without the pedestal of revelation.

Contemporaneous to Ibn Khaldun, a cluster of civilisations were living in harmony under Muslim rule in the vast Islamic geography stretching from Andalusia to Eastern Turkestan. In this order the structure establishing cohesion among the pertinent civilisations regulating inter-civilisational relations were sculpted by Fiqh. The system known today as the Millah system was concurrently representing — in today's expression — all existing civilisations. These included the Catholic, Orthodox, Coptic, Jewish, Magee, Hindu and Buddhist. ${ }^{17}$ Ibn Khaldun, as a judge and scholar of Fiqh, took this pluralistic legal order comprising numerous civilisations and legal codes as a given in Muqaddimah. However, the relevant multi-civilisational order collapsed with the Ottoman downfall.

Bearing in mind today's conditions, the question of whether Ibn Khaldun's sociology of civilisations still retains its validity may justifiably come to mind.

17 Today these social and cultural entities are, as indicated previously, evaluated as religion, culture or civilisation. In the discipline of the history of civilisations, these social structures deemed by Ottoman Fukaha as 'millet' (in Arabic 'millah'), are assessed as civilisations, an approach gradually spreading also in social sciences. For discussions pertaining to the issue, in addition to Huntington's quoted work, also see (Toynbee, 1962). 
We can say with certainty that envisaging the current world order as an unalterable given falls at odds with history. The multi-civilisational social and political order, which had impacted Ibn Khaldun, no longer exists. The multi-civilisational circumstance of today poses a problem for humanity, rendering Ibn Khaldun's sociology of civilisations all the more relevant.

Scholars involved in examining inter-civilisational relations have nowadays assumed two rival factions. Some allege there to be only a single civilisation, namely the Western, with other civilisations having long disappeared. Recent ambassadors of this worldview have been Huntington, Fukuyama and Bernard Lewis. In history, advocates of this approach have invariably been fundamentalist Evangelical Christians and secular Western post-Enlightenment intellectuals. The former group has regarded the Western Christian civilisation, and the latter, its secular civilisation, superior to other civilisations of the world, espousing hegemony through conflict. Eminent sociologists Max Weber and Karl Marx, to a certain extent, also belong in this category. In the opening passages of The Protestant Ethic and the Spirit of Capitalism (Weber 1989), Weber writes at great lengths to prove the superiority of the Western civilisation. He argues that it is a cut above and has given birth to capitalism. Insofar as non-Western civilisations relinquished their developmental qualities and became static, they were unable to follow accordingly. Marx, on the other hand, places the West on the top of the evolutionary table, identifying the East with despotism. From the perspective of relations of production, Marx stigmatises the East under a peculiar category of "the Oriental method of production", isolating it from the contemporary civilisation. Regarding class structure and the mode of production, the West and East are distinct; the latter has regressed, and therefore must emulate the former. Clearly Western imperialism receives legitimisation by the expedient use of economic, political, religious and secularist arguments by those who advocate the existence of but one civilisation in the world.

Conversely, Richard Bulliet, Richard Falk, John Esposito, and similar authors oppose the clash of civilisations thesis. Instead, they argue for coexistence of civilisations. In this regard, the joint project inaugurated by the Turkish and Spanish governments to form an "alliance of civilisations" could provide a useful starting point. The most seminal figure in history of this approach is Ibn Khaldun, despite there being no mention of his name in today's debates. Notwithstanding the fact that Ibn Khaldun had not been so naïve as to render civilisations impermeable to conflict, he never accepted the notion like Huntington or Lewis that different values germinate conflict.

Clashes between civilisations, believed Ibn Khaldun, were not motivated by differences in cultural values, but by aspirations to achieve majd or hege- 
mony (Ibn Khaldun, 1981: II, 539, 542). He repeatedly reminded the reader that all strong civilisations desire their hegemony to be perpetual and boundless and this struggle for power degenerates into an all inclusive conflict.

Conversely, in his work offering advice on how the world ought to be restructured, Huntington acknowledges the contemporary existence of various civilisations that will clash. He was not the first to coin the term 'clash of civilisations'. A missionary, Basil Matthews, published in 1926, a book called Young Islam on Trek: A Study in the Clash of Civilisations (Mathews, 1926). Conspicuous is the mention of "clash of civilisations" in the book's title. Matthews maintained that Islam is an inveterately warlike and barbaric religion and it is utterly irreconcilable with reason and science. ${ }^{18}$ Shortly before the work of Matthews, Arnold Toynbee wrote a similar book entitled: The Western Question in Greece and Turkey: A Study in the Contact of Civilisations (Toynbee, 1923). The negative attitude vis-à-vis multiplicity of civilisations exhibited by Matthews at the turn of the last century survives today as the dominant view and politics of many groups.

The historical antecedents of Huntington's argument are as follows. For him, the Thirty Years War (between Catholics and Protestants) was the last of the great wars of religion in Europe. The Treaty of Westphalia that ended the war inaugurated the modern nation-state based on principles of internal sovereignty. The norm of 'non-intervention in domestic affairs' meant that the Catholic Papacy would no longer be able to dictate its religious and political agenda on independent European states. For Huntington, World War I was a war of imperialism since it led to the collapse of four major empires (Russian, Austro-Hungarian, German, and Ottoman). World War II was a war of nationalism as new states emerged after this war. Prior to World War II, there were only 68 independent nation-states that existed in the world. Due to decolonisation struggles, new states emerged in Sub-Saharan Africa, Asia, and Latin America. Today, there are more than 190 countries that comprise the United Nations. Further, Huntington argues that the Cold War was a war of ideology that divided the world into capitalist and communist camps. In part, he is responding to Fukuyama's claims that ideological conflicts are over. Instead, Huntington is earnest to point out that the next series of wars will be on the basis of colliding civilisations. He specifies eight dominant civilisations: Western, Confucian, Japanese, Islamic, Hindu, Slavic-Orthodox, Latin American, and African.

\footnotetext{
${ }_{18}$ A repetition of the same attitude expressed in an uncanny resemblance in 2006 by Pope Benedict, is interesting insofar as it attests to the persistence of the exact Western attitude as regards the multiplicity of civilisations problem.
} 
The irreconcilable divergences in values between these civilisations, Huntington surmises, will inevitably lead to conflict. Clearly, this is a simplistic argument that pigeonholes human beings into neat boxes. The assumption is that people cannot belong to multiple civilisations simultaneously. For instance, African-American Muslims can belong to, and be the by-product of, many civilisations. Multiple identities are a palpable reality and dissecting communities into these simplistic categories is at best an exercise in bad scholarship. Moreover, it fails to recognise that in today's globalised world, no one civilisation is independent of another. Westernisation of East Asian societies creates fissures between generations. Asian values of community, solidarity, and group consciousness resonate in the West. Due to the shrinking of time and space, humanity may be witnessing the hybridisation of cultures. Finally, the claim that diverse civilisations cannot exist peacefully is fatuous and historically incorrect. A prudent inspection will demonstrate that several of the above civilisations, entirely or at least partially, were living under Muslim governance during the time of Ibn Khaldun. They included the Islamic, African, Hindu, Slavic-Orthodox, and Western. Among the above mentioned, only the Chinese, Japanese and Latin American civilisations had been remote from Muslim rule. If, as Huntington suggested, inter-civilisational differences of culture and values inescapably lead to discord, then how was it that the relevant civilisations under Muslim rule were able to live together for many centuries?

The question remains for our inquiry how to adopt an intra-civilisational and inter-civilisational world order of peace and stability. Phrased plainly, in opposition to Huntington's vision of a world order based on a simple dual logic dividing the world into Western and non-Western camps, Ibn Khaldun provides a reservoir for the founding of a world order predicated upon a multi-valued logic encompassing multiple civilisations. Being a system of thought instituted on a multi-valued logic, Figh in this transformation may provide a substantial source of inspiration.

At present, those searching to establish a multi-civilisational world order need to refer to the tradition of Fiqh and Ibn Khaldun's discipline of 'Umrän. Even today, many Western intellectuals, evocative of the Middle-Ages, perceive multi-civilisations as a threat. Huntington is one of them. By embracing the first attitude delineated above, these intellectuals promote the need for Western civilisation to annex other civilisations by force; and they regard the prospect of a harmonious coexistence of civilisations as unfeasible.

The thesis of the clash of civilisations echoes Western historical experience. It consisted of the struggle to impose upon the West, and then the rest of the world, a single denomination of Christianity during the Middle-Ages, and a 
single ideology following the Enlightenment. Neither Western theologians flourishing throughout the Middle-Ages, nor the secular thinkers of the modern era, were successful in formulating a conceptual apparatus to adequately solve the problem of plurality of civilisations. Thus, while internal conflicts within the West were widespread, clashes between the Western civilisation and others accentuated divisions. The Islamic civilisation has invariably occupied the hub of these pertinent clashes.

The method of classifying the world into distinct civilisations and of interpreting international relations accordingly has been eclipsed from the 1950's by theories of modernism and development. One important observer of this latter approach is Daniel Lerner (1965). His line of reasoning trivialises religion, and sees it as an ephemeral factor battling futilely the forces of modernism. In retrospect, the theory of modernism had been founded upon a presumption of superiority, while expecting non-Western civilisations to increasingly embrace secular-Western culture as the only viable civilisation. The Emergence of Modern Turkey, the optimistic work by Lewis written in the same period could be regarded as a reflection of the modernist theory (Lewis 2002). The best thing Muslims can do, Lewis argued, was to abandon the Islamic civilisation and voluntarily adopt the Western civilisation.

In a work entitled The Case for Islamo-Christian Civilisation, Richard Bulliet had put forth an antithesis critical of Lewis and Huntington (Bulliet 2004). Accordingly, from the angle of historical experiences, Islam and Christianity cannot be used as fodder for civilisational clashes. Conversely, the historical experiences of both civilisations are inextricably intertwined. In the book, Bulliet makes a strong case in defence of the close reciprocal relations throughout history between Islam and Christianity. Bulliet contended that the Islamic and Christian civilisations have many commonalities that can be used as a bulwark to establish harmonious relations. More than explicating and solving the multiplicity of civilisations, Bulliet's work is aimed generally toward illustrating the historical nearness between Islamic and Christian civilisations.

Our central aim here is not to identify the advocates and opponents of the thesis of the clash of civilisations. Instead, the goal here is to probe into the reasons as to why the approach of Ibn Khaldun is persistently ignored in pertaining debates. After all, he is the founder of the discipline of 'Umrān and the one who applied civilisation to theories in political science and international relations. The outlook of Ibn Khaldun has yet to be adopted in discussions of civilisational clashes. This remarkable display of negligence resonates throughout the intellectual community, both Muslim and non-Muslim alike.

We have hitherto succinctly offered a comparative presentation of positive and negative viewpoints vis-à-vis a multi-civilisational world order. Despite 
deserving a privileged position as a sociologist of a multi-civilisational approach, Ibn Khaldun is not given the importance he merits. As we have already attempted to validate, however, Ibn Khaldun proffers a solid theoretical foundation to those who are trying to build a multi-civilisational order in our globalised world.

\section{Inter-civilisational Relations}

There are glaring differences between Ibn Khaldun and Huntington. However, there is an intriguing commonality between them. Both assign enormous importance to the relations and conflicts among civilisations in reconfiguring international relations. Also, both accept the importance of the relations among civilisations in determining the future of each. Such an approach breaks considerably from previous attempts of explicating the history of a specific civilisation by looking exclusively at its internal dynamics, conflicts, and crises. For instance, from this latter perspective which disregards external relations between civilisations, the collapse of Islamic civilisation is attributed exclusively to its internal problems. Concurrently, the rise of the West is also attributed solely to its internal virtues. Likewise, from such an approach, Islam is viewed as 'backward', and the backwardness is ascribed to its internal dynamics. This logic neglects centuries of external assaults and colonial onslaughts that the Islamic civilisation has had to endure. In contrast, Ibn Khaldun and Huntington draw attention to the role of external factors on the venture of a civilisation. The Ibn Khaldunian approach, alternately, maintains the requisite of using both internal and external reasons, comparatively, in explaining the venture of civilisations. Embarking from this approach, the discourse of 'backwardness' of the Islamic civilisation has become commonplace among intellectuals and academicians who accept it without critical analysis. Yet it presents nothing beyond an account based only on internal dynamics. This lack of attention to external variables makes the discourse of backwardness lose much of its virtue. As such, the Islamic civilisation has not regressed by itself; it has instead been thus far defeated and colonised following centuries of battles.

Proceeding from Ibn Khaldun, it could be asserted that the Islamic civilisation and the Ottomans collapsed as they had reached their apex. Ibn Khaldun argues that in prosperous societies, excessive progress, not backwardness, undermines the spirit of warfare and aptitude to defend against foreign attacks. From this perspective, the failure of the Islamic civilisation and its last major representative (the Ottomans) can be attributed to the weakening 
group-spirit ('asabiyya) which was necessary to withstand external attacks. Among these are the loss of Jerusalem to Crusaders, Andalusia to the Spanish, Baghdad to Mongols and the Ottoman defeat in WWI. In all these cases of defeat and invasion, history testifies that Muslims had a more developed civilisation compared to their enemies.

Strong civilisations, Ibn Khaldun contends, are imitated by the weak. However, can a civilisation be equally strong in all areas? Today, regarding the attributes which Ibn Khaldun labels as the accidental qualities of a civilisation, the West looks preeminent. Thus, actuality has an overpowering status in preference to theoretical disputes. Masses allow actuality to be the judge in deciding the strength of a civilisation that they emulate.

Cultural and religious values endow the Islamic world with pre-eminence over the West even though it is comparatively weak militarily, technologically, and economically. Hence, the ultimate victor in the scuffle between the Western and Islamic civilisations has yet to be determined. While Islam prolongs its global ascendancy, particularly in the West as the fastest growing religion in the world, ironically the Western armies are intervening, even overrunning various parts of the Islamic world. Sharply expressed, Islam is in the process of a cultural conquest, while the West, a military one.

In contrast, the Western civilisation is increasingly relinquishing all spiritual and ethical claims, becoming consigned to a culturally feeble position. However, in the Islamic world, there is a spiritual revival, and a 'return to roots' phenomenon. At the same time, there is a secular tendency in the Islamic world where many Muslims imitate the material experience of the Western civilisation. While Islam retains the status of being the fastest growing religion in the West, Westernisation is relentlessly persevering in the Islamic world. Thus, for either side, absolute superiority seems improbable.

The rise and fall of a civilisation, Ibn Khaldun holds, is never eternal. According to Ibn Khaldun's sociology of civilisations, the fundamental dynamic of history is the continuous cycle of civilisations. Linearity, in other words, is historically impossible and ascending or declining perennially is unviable. Instead, the more prevalent are cycles of rise and decline.

Perusing the Western civilisation embarking from Ibn Khaldun's 'Umrān theory, it is possible to extrapolate two ideas. First, the rise of the Western world, otherwise known as modern civilisation, has like others an end. Envisioning her everlasting survival runs counter to the basic laws of history. Secondly, the end of Western civilisation will befall subsequent to its attaining high levels of perfection. Increasing prosperity is bound to weaken modern societies' ability of defence, paving the way for the rise of other imperial societies. 
So long as the cultural, military, technological and economic supremacy of Western civilisation continues, other civilisations will continue to emulate the West. Thus the potential source of change lies in altering the balance of power. During its zenith, the Islamic civilisation elicited the imitation of members of other civilisations. However, with the rise of the Western civilisation, each and every civilisation in the world, including the Islamic, entered an uncritical and uncompromising race toward Western emulation.

Efforts of westernisation and modernisation, however, by non-Western societies have invariably failed. Discounting the controversial case of Japan, it is impossible to indicate an example that has had complete success in achieving westernisation and modernisation to its utmost. This process of westernisation has been both symbolic and politically and economically transformative. It is reflected in attire, the adoption of Western legal codes, and an economic worldview based on liberal notions of openness and economic integration with the world economy. Its ultimate goal is to create homogeneity among the multifarious civilisations of the world.

Imitation of the strong civilisation by the weak culminates in inter-civilisational addiction, attested by the varying degree of dependence on the West by non-Western civilisations. Non-Western civilisations are compelled to import, from the West, not only technological goods, but also productions of thought.

\section{Conclusion: The Ibn Khaldun Paradox or the Circulation of Civilisations}

Ibn Khaldun's discipline of 'Umrān is founded on a paradox. According to him, civilisations begin to collapse not as a result of their backwardness, but after they have reached the apex of progress. Consequently, as argued above, the Islamic civilisation and its last great representative the Ottomans collapsed after becoming prosperous par excellence. Once the Western civilisation procures the greatest frontiers of its development, so will it begin its downfall. Paradoxically, the warrior spirit and ability of self-defence dwindles in civilisations whose opulence increases. Hence, supreme triumph is tantamount to the end of a civilisation.

The history of civilisations, Ibn Khaldun avows, is replete with paradoxes and ironies, perhaps the most pivotal of which is the transformation of the perfection of civilisations leading to demise (Ibn Khaldun, 1981, II, 542.). This may also be called the 'continuous cycle of civilisations' or the 'continual transformation of civilisations'. The continuous cycle of civilisations aspiring toward global ascendancy and the subsequent fall, Ibn Khaldun believes, is 
inescapable. Circulation of civilisations, according to Ibn Khaldun, is a historical canon impervious to defiance or alteration by the human will.

Complementing the material approach of Ibn Khaldun's 'Umrān theory is the spiritual or cultural approach of the Fuqaha. While the discipline of 'Umrān analyses, on the macro level, political and economic relations, Fiqh examines cultural relations on the micro level. The former conducts an empirical analysis of inter-civilisational affairs, while Fiqh attempts to arrange those very affairs normatively. Therefore, Figh does not exclusively proclaim norms regulative of Muslim life per se; it equally regulates, albeit limitedly, the relations of non-Muslim societies (Millahs) residing in Muslim domains. Within this framework, non-Muslims, referred to as dhimmi, preserve their civilisational identities. According to Ibn Khaldun, 'Umrān is anchored in Fiqh. Consequently, it becomes evident that there was a reciprocal relationship and mutual utilisation of both Figh and 'Umrān in traditional Islamic and Ottoman-Turkish thought.

There exists a possibility, also today, of scrutinising inter-civilisational relations by conducting sociological macro analyses like that of Ibn Khaldun. Ibn Khaldun's momentous discipline of 'Umrän and the tradition of Fiqh may shed light on those desiring to reinterpret the inter-civilisational relations of today and recast it in a more pluralistic and peaceful mould.

For Ibn Khaldun, History with capital " $\mathrm{H}$ " does not exist and its cessation is unthinkable. In defiance of Fukuyama's allegation, history has not ended and cannot end; the West has been unable to - and cannot in the future incorporate all other civilisations in the world. Gazing into the future from the vantage point of Ibn Khaldun's 'Umrān approach, we can craft a viable model to construct a multi-civilisational world. Again, an Ibn Khaldunian worldview, as epitomised in the circulation of civilisations, might hint at the irredeemable failure of forging an everlasting Western dominance over the rest of the world. History is replete with examples of the rise and decline of civilisations.

In brief, future inter-civilisational relations will continue to be imbued with paradoxes and ironies, proceeding spirally on a rollercoaster journey, as it has been throughout history. If Ibn Khaldun's circular conception of history and multi-civilisational world theory carries any veracity, it could justify the verity of thinkers who nurture a small lettered notion of civilisations, at the detriment of Civilisation and a small lettered notion of history at the detriment of History. Thus, throughout this process of explicating and understanding intercivilisational relations, the discipline of 'Umrān (science of civilisation), and the discipline of Fiqh may just provide inspirational sources. 


\section{References}

Abdurrahman Ibn Khaldun (1951) Al-Tarif Ibn Khaldun wa Rihlatuh Sharqan wa Gharban (ed. Muhammad Tavit al-Tanji), Cairo: Lajnah al-Ta'lif wa al-Tarjumah wa al-Nashr,.

Arnold Joseph Toynbee ( 1962) A Study of History, London: Oxford University Press,.

Arnold Toynbee (1923) The Western Question in Greece and Turkey: A Study in the Contact of Civilisations, Boston: Houghton Mifflin.

Aziz Al-Azmeh (1981) Ibn Khaldun in Modern Scholarship (London: Third World Centre. (1982) Ibn Khaldun, New York: Routledge.

Basil Mathews (1926) Young Islam on Trek: A Study in the Clash of Civilisations, New York, Friendship Press.

Bernard Lewis (2002) The Emergence of Modern Turkey, Oxford: Oxford University Press.

Bruce Lawrence (1983) "Ibn Khaldun and Islamic Reform", Journal of Asian and African Studies, XVIII(3-4):. 221-240.

(1983) "Preface", Journal of Asian and African Studies, XVIII(3-4).

Cornell Fleischer (1983), "Royal Authority, Dynastic Cyclism and 'Ibn Khaldunism' in Sixteenth Century Ottoman Letters”, Journal of Asian and African Studies, XVIII, (3-4): 198-220.

Daniel Lerner (1965) The Passing of Traditional Society: Modernizing the Middle East, New York: The Free Press.

Francis Fukuyama (1992) The End of History and the Last Man, New York: Free Press.

Franz Rosenthal (1983) "Ibn Khaldun in His Time", Journal of Asian and African Studies, XVIII(3-4) :166-178.

Hamilton A. R. Gibb (1962) Studies on the Civilisation of Islam (ed. Stanford Shaw-William R. Polk), London: Routledge-Kegan Paul Limited, pp. 166-175.

Huntington, Samuel P. (1996) The Clash of Civilizations and the Remaking of World Order, New York, Simon \& Schuster.

Ibn Khaldun (1981) Muqaddimah I-III (ed. Ali Abdulwāhid al-Wāfî), Cairo: Dar-u Nahdat-i Misr,.

(1275) Tercüme-i Mukaddime-i İbn Haldûn (trns. Pîrîzâde Mehmed Sâhib Efendi), Bulak: Matbaa-i Âmire,).

Kalman Bland (1983) "An Islamic Theory of Jewish History: The Case of Ibn Khaldun", Journal of Asian and African Studies, XVIII(3-4): 189-197.

Max Weber (1989) The Protestant Ethic and the Spirit of Capitalism (trc. Talcott Parsons), London: Unwin Hyman.

Noam Pianko (2006) "Reconstructing Judaism, Reconstructing America: The Sources and Functions of Mordecai Kaplan's "Civilisation", Jewish Social Studies, new series 12/2, pp. 39-55.

Richard Bulliet (2004) The Case for Islamo-Christian Civilisation, New York: Columbia University Press,.

William H. Sewell (1992) "A Theory of Structure: Duality, Agency and Transformation", American Journal of Sociology, 98, pp. 1-29.

Yves Lacoste (1984) Ibn Khaldun: The Birth of History and the Past of Third World (New York: Verso,) pp. 149-150.

Zaid Ahmad (2003) The Epistemology of Ibn Khaldūn, New York: Routledge and Curzon. 
Copyright of Asian Journal of Social Science is the property of Brill Academic Publishers and its content may not be copied or emailed to multiple sites or posted to a listserv without the copyright holder's express written permission. However, users may print, download, or email articles for individual use. 